\title{
Training of Cadres In The Context of Emergency Identification of Pregnant Women During The Covid-19 Pandemic
}

\author{
Dyah Puji Astutia), Kusumastuti, and Rosmawati \\ Universitas Muhammadiyah Gombong, Gombong, Indonesia \\ a)Corresponding author: dyahpuji090384@gmail.com
}

\begin{abstract}
The Covid-19 pandemic has changed many things, including the policy direction for the schedule of examinations for pregnant women, which was initially at least four times during pregnancy to one time, as long as the pregnancy is not problematic. In the midst of the COVID-19 pandemic, many pregnant women are reluctant to check their pregnancy at the hospital for fear of contracting the Corona virus, even though pregnancy checks still need to be carried out regularly. The purpose of this community service is to provide training to health cadres regarding emergencies in pregnancy so that cadres can provide assistance in order to identify emergency conditions during pregnancy during the COVID-19 pandemic. The method of activities carried out is cadre training and assistance to pregnant women. The results showed that after the training activities, the level of knowledge of cadres on emergency services in pregnant women increased and pregnant women in the high risk category were $53.7 \%$. In conclusion, this community service program has succeeded in increasing the knowledge of cadres in assisting pregnant women during the COVID-19 pandemic.
\end{abstract}

Keywords: Cadres, training, emergency, pregnant women, covid 19

\section{INTRODUCTION}

The Covid-19 pandemic has changed many things, including the policy direction for the schedule of examinations for pregnant women, which was originally a minimum of four times during pregnancy to just once, as long as the pregnancy is not problematic. During the COVID-19 pandemic, many pregnant women are reluctant to check their pregnancy at the hospital for fear of contracting the Coronavirus, even though pregnancy checks still need to be carried out regularly. For pregnant women, if there is no urgent need, it is recommended not to travel outside the house let alone to the hospital. Even though pregnancy checks still need to be carried out regularly to find out the progress of pregnancy and detect early if there are problems with the pregnancy, both for the mother and the fetus (POGI. 2020).

The Covid-19 pandemic targets all groups, including vulnerable groups such as pregnant women. It is not only the issue of transmission that is the direct impact of Covid-19. However, many indirect implications have received little attention at this time, namely regarding access to health services for women from the stage of pregnancy to delivery. The World Health Organization (WHO) states that strict health care during a pandemic will have an impact on the utilization of health services, especially reproductive health services. Several obstacles in utilizing health services were experienced by pregnant women during this pandemic. For example, pregnancy checks should be done regularly.

For this reason, it is necessary to assist pregnant women both online and in face-to-face meetings while still paying attention to health protocols to prevent the spread of the Coronavirus. The purpose of the assistance is so that pregnant women know and be alert independently of signs of problems in pregnancy that will harm the mother and fetus, so they must come to the hospital for an examination (dr Arlina, 2019).

Assistance for pregnant women is one of the government's programs to reduce Maternal Mortality Rate (MMR) and Infant Mortality Rate (IMR). The program, which focuses on groups of pregnant women at risk, is a field activity to improve maternal safety. In assisting pregnant women will not be separated from social capital. Assistance for pregnant women by cadres is a form of active community participation where cadres as companions carry out ongoing 
interactions with pregnant women. Things that are provided during mentoring include: introducing danger signs to pregnant women and examination procedures if pregnant women are forced to carry out examinations at health service facilities so that they hope to achieve optimal health for pregnant women during this covid 19 pandemic (Kemenkes.RI. 2020).

Madureso Village is located in the Kuwarasan District, Kebumen Regency. Madureso village has a lowland geographical area with rice fields. Source of water for daily consumption from well water. Consists of $5 \mathrm{RW}$ and $14 \mathrm{RT}$ with the distance between RW separated by rice fields and yards. The number of households in Madureso village is 964, with a population of 3274 people consisting of 1,705 male residents and 1,569 female residents. With a livelihood, most of the population is farming and trading. Most of the community's education level is elementary and junior high school, which is around $63 \%$. There are religious facilities in Madureso village, namely 1 mosque, 5 prayer rooms, while for educational facilities there are 1 SDN, 1 Madrasah Ibtidaiyah. In the Maternal and Child Health data, there are 36 pregnant women, 225 children under five, and 11 postpartum mothers. Socio-cultural conditions, most of them are Muslim, come from Javanese ethnicity, can speak Javanese and some use Indonesian communication. The number of pregnant women in Madureso Village is 26 pregnant women. The number of health cadres is 24 people but have never received special training regarding emergencies in pregnancy. Based on information from one of the pregnant women. During this pandemic, pregnant women rarely go to health facilities because of the limited schedule of visits to the Public Health Center (Puskesmas) and the Independent Practice Midwife. Pregnant women are allowed to visit. The

The purpose of this community service activity is to provide training to health cadres regarding emergencies in pregnancy so that cadres can assist in identifying emergency conditions during pregnancy during the COVID-19 pandemic.

\section{METHOD}

Community service activities are carried out through training activities for cadres carried out in Madureso Village, Kuwarasan District, Kebumen Regency. This activity was carried out for 3 months from January to March 2021. The population in this activity were all cadres and pregnant women in Madureso Village. The number of cadres is 23 people and pregnant women are 28 people. The sampling technique used is total sampling. Data collection techniques are carried out through activities.

Methods of carrying out activities are as follows: 1). Cadre Training: Cadre training activities will be carried out through virtual meetings through the zoom application. This activity, it is explained how the emergency detection process using PPT and Booklet materials is explained. This activity also explained screening through a history of examination data for pregnant women through the $\mathrm{MCH}$ Handbook. 2). Measurement of the level of knowledge of cadres: The activity of measuring the level of knowledge of cadres using a google form questionnaire that will be measured before training and after training activities for cadres. This is to see changes in the level of knowledge by cadres and ensure the training of cadres before carrying out mentoring activities for pregnant women. 3). The assistance of trained cadres to mothers; Cadre assistance is carried out through house-tohouse visits. The number of cadres who make home visits will be regulated based on the number of pregnant women in Madureso Village. The assistance of cadres to pregnant women is to obtain data on the history of examinations of pregnant women, and the current condition of pregnant women based on a mentoring questionnaire that has been prepared by the community service team. 4). Identification of the health condition of pregnant women by trained cadres: This identification activity is carried out to obtain data on whether pregnant women who are accompanied by cadres have an emergency condition. If there is an emergency condition, the cadres will carry out a referral process to the village midwife as a 
follow-up to efforts to assist pregnant women during the pandemic so that they can be monitored intensively by the cadres and the Madureso Village Midwife. 5) Evaluation; Evaluation is done by looking at the data on assistance provided by cadres. The evaluation is also carried out in conjunction with the Village Midwife to ensure the sustainability of the evaluation of the service program that has been carried out

\section{RESULTS}

Characteristics of cadre respondents from 23 people consisted of 15 cadres over 35 years old $(65.2 \%), 8$ cadres $(34.8 \%)$. Respondents of pregnant women as many as 28 pregnant women based on age category then grouped in the category of healthy reproductive age (20-35 years) as many as 25 people $(89.3 \%)$ and 3 people $(10.7 \%)$ in the category of unhealthy reproductive age ( $>35$ years) multigravida as many as 17 people (60.7\%). Primigravida as many as 17 people (60.7\%), multigravida as many as 9 people (32.2\%), and multigravida as many as 2 people $(7.1 \%)$.

The level of knowledge of cadres regarding emergencies in pregnant women obtained pre-test and post data, namely before the pretest cadres with good knowledge were 6 people (26.1\%), enough for 13 people (56.5\%) and less than 4 people (17.4\% ). Meanwhile, the results of the posttest showed that 15 people (65.2\%) had good knowledge and 8 people (34.8\%) had sufficient knowledge. The results of the identification of cadres on emergency conditions during the covid pandemic and risk factors obtained were 15 people $(53.6 \%)$ and all 28 pregnant women (100\%) had no symptoms of covid 19 . This shows that there are still mothers pregnant with unhealthy reproduction as many as 3 people $(10.7 \%)$, multigravida as many as 2 people (7.1\%).

\section{DISCUSSION}

Age characteristics of cadres related to age can affect a person's work productivity, age also affects the views of officers towards superiors and patients. The results of this questionnaire are supported by research by Elita (2011) in Mustikaningsih (2020), stating that age will affect the character in studying, understanding, and accepting a change so that it will affect the quality and quantity of one's work. Age can affect work productivity because a person's ability to work is limited by the age factor.

Pregnant women were found to still have risk factors. According to Khadijah (2018), a high-risk pregnancy is a pregnancy that will cause greater danger and complications to both the mother and the fetus in the womb and can cause death, illness, disability, discomfort, and dissatisfaction. Thus, to deal with pregnancy or high-risk fetuses, a proactive attitude must be taken, planning with promotive and preventive efforts. The promotive and preventive efforts carried out with this service are through cadre assistance activities for emergencies in pregnancy so that pregnant women are expected to know the conditions experienced and immediately go to the referral facility if they experience one of the emergency conditions.

High-risk factors before pregnancy are divided into a) genetic factors, namely heredity factors and environmental factors that are influenced by education and social. b) High-risk factors that work during pregnancy or conditions that can stimulate pregnancy. Mother's habits such as smoking, drinking alcohol, drug addiction, etc. Diseases that affect pregnancy eg gestational hypertension, toxemia gravidarum. c) Risk factors during delivery d. Risk factors in neonates.

Knowledge of cadres about emergencies in pregnancy has increased from pretest and posttest. In the author's opinion, after being given material exposure activities through knowledge training about the benefits of early detection of emergencies in pregnancy, a cadre has a positive attitude and will influence mothers to carry out early detection of highrisk pregnancies and checkups. antenatal care as early as possible to health workers. 


\section{CONCLUSIONS And RECOMMENDATIONS}

Cadre training activities for Cadre Training in the Context of Emergency Identification of Pregnant Women During the Covid 19 Pandemic is a form of Cooperation between the University of Muhammadiyah Gombong and the village of Madureso as a form of implementing the tri dharma activities of higher education. The service implementation activities went smoothly and went well, as evidenced by changes in the level of knowledge of health cadres between pre and post-tests regarding emergencies in pregnant women in the covid pandemic. However, in assisting pregnant women, data on pregnant women who are at risk are still obtained from factors such as age, parity, and past obstetric history. So it is recommended for health cadres and village midwives to continue to monitor the health of pregnant women until the delivery process so that optimal health can be achieved for mothers and babies born.

\section{ACKNOWLEDGMENTS}

Thank you to the Rector Universitas Muhammadiyah Gombong, and Head of Research Institute and Community Service of Universitas Muhammadiyah Gombong, the Head of Madureso Village, Kuwarasan District who have provided assistance, support, and contributed to the implementation of community service and the completion of the preparation of this report.

\section{REFERENCES}

ACOG. Practice Advisory : Novel Coronavirus 2019 (COVID-19). American College of Obstetric and Gynaecology. 2020

Direktorat Jendral Pencegahan dan Pengendalian Penyakit. 2020. POGI. Rekomendasi Penanganan Infeksi Virus Corona (Covid-19) Pada Maternal (Hamil, Bersalin Dan Nifas). Indonesia: POGI. 2020

Dr. dr Arlina D, dkk. 2019. Deteksi Dini Resiko Tinggi Bagi Kader Kesehatan. Leutkoprio. Jogyakarta

Kemenkes RI . 2020. Pedoman Bagi Ibu Hamil, Bersalin, Nifas dan Bayi Baru Lahir di Era Pandemik Covid 19. Jakarta: Kemenkes RI

Kemenkes.RI. 2020. Pedoman Bagi Ibu Hamil, Bersalin, Nifas, dan Bayi Baru Lahir di Era Pandemi Covid-19.Indonesia: Kemenkes RI.

Kemenkes RI.2020. Pedoman Kesiapsiagaan Menghadapi Infeksi Novel Coronavirus (2019nCov).

Khadijah, 2018. Upaya Deteksi Dini Resiko Tinggi Kehamilan Ditentukan Oleh Pengetahuan Dan Dukungan Tenaga Kesehatan. Jurnal Sehat Mandiri, Volume 13 No 1 Juni 2018 p-ISSN 19708-8517, e-ISSN 2615-8760

Mustikaningsih, 2020: Pendampingan dan Sosialisasi Peran Supervisor Model 4S Dalam Membimbing Perilaku Caring Perawat dan Pelaksanaan Spiritual Care Islam, Jurnal Pengabdian Kepada Masyarakat LPPM-Universitas Muhammadiyah Tasikmalaya Volume: 4 Nomor: 1, E-ISSN: 2614 - 8544

RCOG.Coronavirus (COVID-19) Infection in Pregnancy. Versi 1.9 Maret 2020 WHO. Pencegahan dan pengendalian Infeksi (PPI) untuk Novel Coronavirus (COVID-19). WHO. 2020.

Rekomendasi POGI. 2020. Penanganan Infeksi Virus Corona (COVID-19) pada Maternal (Hamil, Bersalin dan Nifas)

Santoso, HD \& Santoso A. 2020. Covid 19 dalam Ragam Tinjauan Perspektif. MbrigdePress 


\section{APPENDIX}

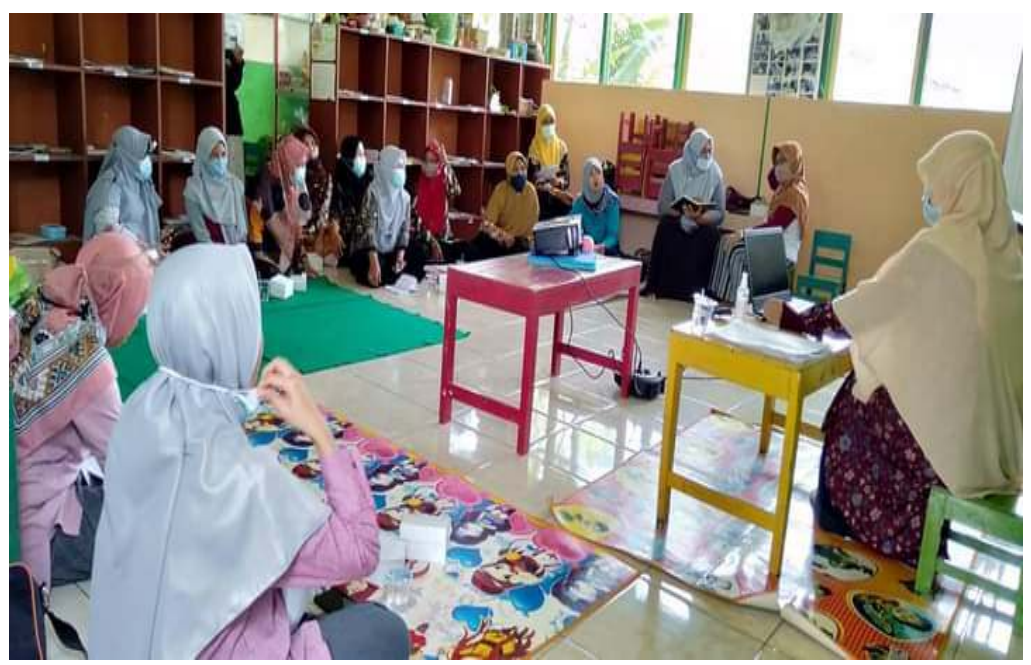

Figure 1. Cadre Training 1

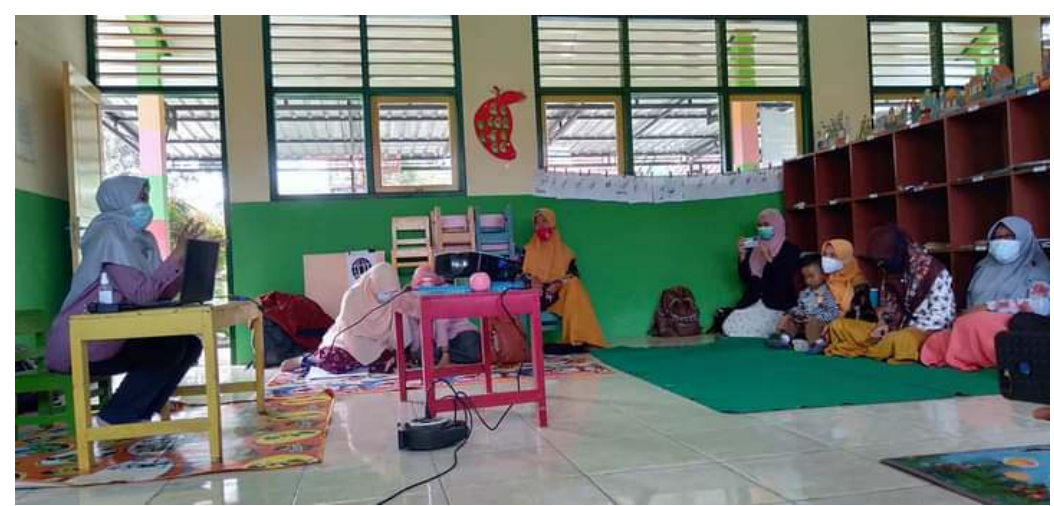

Figure 2. Cadre Training 2 